\title{
Az akut vestibularis szindróma sürgósségi diagnosztikájával szerzett tapasztalatok
}

\author{
Tamás T. László dr. ${ }^{1}$ - Garai Tibor dr. $^{1}$ - Király István dr. ${ }^{2}$ \\ Mike Andrea dr. ${ }^{3}$ - Nagy Csaba dr. ${ }^{2}$ - Paukovics Ágnes dr. ${ }^{4}$ \\ Schmidt Péter dr. ${ }^{5,6}$. Szatmári Ferenc dr. ${ }^{4}$. Tompos Tamás dr. ${ }^{1}$ \\ Vadvári Árpád dr. ${ }^{2}$ - Szirmai Ágnes dr. ${ }^{7}$
}

${ }^{1}$ Petz Aladár Megyei Oktató Kórház, Fül-Orr-Gégészeti és Fej-, Nyaksebészeti Osztály, Győr ${ }^{2}$ Markusovszky Lajos Egyetemi Oktató Kórház, Radiológiai Osztály, Szombathely ${ }^{3}$ Petz Aladár Megyei Oktató Kórház, Neurológiai Osztály, Győr

${ }^{4}$ Affidea Diagnosztika Magyarország Kft., Győr

${ }^{5}$ Semmelweis Egyetem, Általános Orvostudományi Kar, Egyetemi Oktató Rendelő, Győr

${ }^{6}$ Magyar Tudományos Akadémia IX. Osztály, Statisztikai és Jövőkutatási Bizottság, Budapest ${ }^{7}$ Semmelweis Egyetem, Általános Orvostudományi Kar, Fül-Orr-Gégészeti és Fej-Nyaksebészeti Klinika, Budapest

\begin{abstract}
Bevezetés és célkitüzés: A szemmozgások analízisén és az akut halláscsökkenés detektálásán alapuló 1A evidenciájú új diagnosztikai módszer hatékonyságának vizsgálata akut vestibularis szindrómákban. A perifériás és a centrális eredetű vestibularis kórképek és az izolált szédüléssel jelentkező hátsóscala-területi stroke-ok előfordulási gyakoriságának elemzése. A stroke kizárása céljából végzett sürgősségi koponya komputertomográfiás vizsgálat diagnosztikus értékének a felmérése. Egy videookulográfiás szemüveg és az audiológiai vizsgálat segítségével végzett eszközös és az eszköz nélküli, ágy melletti módszer diagnosztikai hatékonyságának az összehasonlítása.

Módszer: Egy prospektív tanulmány során a győri Petz Aladár Megyei Oktató Kórház Sürgősségi Osztályán akut vestibularis szindrómával jelentkező 125 páciensnél (62 nő, 63 férfi, átlagéletkor 53 év) 2016. március 1 . és 2017. március 1. között koponya komputertomográfiás vizsgálatot követően az ágy melletti fizikális, múszer nélküli és a kvantitatív, múszeres, a szemmozgások analízisén és az akut halláscsökkenés detektálásán alapuló vizsgálatot végeztük el egy video-fejimpulzusteszt szemüveg- és tisztahang-küszöb audiometriai vizsgálat segítségével. A kiszúrt strokeesetek neuroradiológiai verifikálását végeztük koponya mágneses rezonanciás képalkotás alkalmazásával.

Eredmények: Az eszközös vizsgálati módszerrel detektálva az AVS-ek 67\%-a perifériás, 33\%-a centrális eredetűnek bizonyult. A hátsóscala-stroke-ok 62\%-a izolált szédüléssel jelentkezett, egyéb neurológiai kísérő tünet nélkül, és a stroke kizárására akutan elvégzett koponya-CT-k eredménye az esetek 96\%-ában negatív volt. Az eszközös teszt a fizikális vizsgálat hatékonyságát javította, mivel detektálta a neuronitis inferior és a csak covert saccaddal kísért neuronitis superior eseteket.

Következtetések: Az új, ágy melletti vizsgálati módszer, tapasztalataink szerint, alkalmas az izolált szédüléssel jelentkező hátsóscala-stroke-ok kiszúrésére a diagnosztika korai szakában, amikor a neuroradiológiai diagnosztika még alacsony szenzitivitású vagy nem elérhető.
\end{abstract}

Orv Hetil. 2017; 158(51): 2029-2040.

Kulcsszavak: fejimpulzus, neuronitis vestibularis, stroke, sürgősségi, szédülés

\section{Emergency diagnosis of the acute vestibular syndrome}

Introduction and aim: To diagnose acute vestibular syndrome (AVS) in a prospective study by a new bedside test (providing IA evidence) based on oculomotor analysis and assessment of hearing loss. To assess the frequency of central and peripheral causes of acute vestibular syndrome in the emergency room. To establish the diagnostic accuracy of acute cranial computed tomography as compared to oculomotor analysis done by video oculography goggles and audiometry. 
Method: Between lst March 2016 and lst March 2017 we documented 125 patients (62 women, 63 men, average age 53 years) in the emergency room of the Petz Aladár County Teaching Hospital using the above bedside and instrumental testing. Diagnosis was verified by cranial magnetic resonance imaging.

Results: According to the results of the instrumental examination in AVS in 67\% we found a peripheral cause and in $33 \%$ a central pathology. In $62 \%$ isolated posterior circulation stroke manifested itself by isolated vertigo without additional focal signs and the acute cranial computed tomography showed negative results in $96 \%$. The instrumental examination increased diagnostic accuracy by making the diagnosis of isolated inferior semicircular canal vestibular neuritis possible.

Conclusions: The new bedside oculomotor test is suitable for the diagnosis of posterior circulation stroke manifesting with isolated vertigo in early cases, when the routine neuroradiologic methods have a lower sensitivity or are not available.

Keywords: dizziness, emergency, head impulse, stroke, vestibular neuritis

Tamás TL, Garai T, Király I, Mike A, Nagy Cs, Paukovics Á, Schmidt P, Szatmári F, Tompos T, Vadvári Á, Szirmai Á. [Emergency diagnosis of the acute vestibular syndrome]. Orv Hetil. 2017; 158(51): 2029-2040.

(Beérkezett: 2017. augusztus 11.; elfogadva: 2017. szeptember 7.)

\section{Rövidítések}

ABCD2 = (Age) kor, (Blood pressure) vérnyomás, (Clinical features) klinikum, (Duration of symptoms) a tünetek fennállásának időtartama, Diabetes; AICA = arteria cerebelli inferior anterior; AVS = akut vestibularis szindróma; $\mathrm{CT}=$ komputertomográfia; CTA = komputertomográfiás angiográfia; DWI = diffusion-weighted imaging; FFE $=$ fast field echo; FLAIR = fluid-attenuated inversion recovery; HINTS-teszt $=($ Head Impulse test) fejimpulzusteszt, (direction-changing Nystagmus) irányváltó nystagmus, (Test of Skew deviation) a skew deviáció vizsgálata; INFARCT $=($ Impulse Normal $)$ normális fejimpulzusteszt, (Fast-phase Alternating) váltakozó gyors fázis, (Refixation on Cover Test) refixáció a cover teszten; LARP $=($ left anterior-right posterior) bal első-jobb hátsó; $\mathrm{MRA}=$ mágneses rezonanciás angiográfia; $\mathrm{MRI}=$ mágneses rezonanciás képalkotás (imaging); $\mathrm{PCA}=$ arteria cerebri posterior; $\mathrm{PICA}=$ arteria cerebelli inferior posterior; RALP $=$ (right anterior-left posterior) jobb első-bal hátsó; $\mathrm{SBO}=$ sürgősségi betegellátó osztály; SCA = arteria cerebelli superior; TFE = turbo field echo; TIA = tranziens ischaemiás attak; TSE $=$ turbo spin echo; $\mathrm{USB}=$ universal serial bus; TTTET $=($ Triage - Timing - Trigger - Targe ted Examination - Test) prioritási sorrend - időtartam és ismétlődés - provokáló tényező - célzott vizsgálat-teszt; VB = vertebrobasilaris; $\mathrm{VOG}=$ videookulográfia $; \mathrm{VOR}=$ vestibuloocularis reflex

Magyarországon a betegek 3\%-a elsődlegesen szédülés miatt érkezik a sürgősségi betegellátó osztályra ( $\mathrm{SBO})$ [1]. A győri Petz Aladár Megyei Oktató Kórház SBOján végzett retrospektív, öt hónapos időtartamot felölelő felmérésben naponta átlag 2,76 beteg jelentkezett szédülés miatt, és ezeknek a betegeknek a $79 \%$-a élete első szédüléses epizódját élte át [2]. Az elmúlt évtizedben ugrásszerúen javultak a klinikai gyakorlatban alkalmazható diagnosztikai és terápiás módszerek, amelyek segítségével a betegek jelentős hányadában a szédülés hátte- rében álló ok meghatározható és az esetek többségében a panasz megszüntethető.

A sürgősségi ellátásban szédülés panaszával jelentkező beteg esetében a legfontosabb annak felmérése, hogy fennáll-e életet veszélyeztető vagy súlyos egészségkárosodással fenyegető kórkép. Emellett törekedni kell a szédülés hátterében álló kórok minél pontosabb megállapítására, mert ennek és a megfelelő terápia alkalmazásának elmaradása a szédülés fennállását prolongálhatja, következményesen a beteg életminősége jelentősen romolhat, megnóhet az elesések kockázata, krónikus panaszok és az organikus elváltozásokra ráépülő pszichiátriai tünetek alakulhatnak ki. A diagnózis felállításának elmaradása felesleges diagnosztikai vizsgálatokat fog eredményezni, amelyek indokolatlanul terhelik a beteget és növelik a kiadásokat.

A sürgősségi diagnosztikának jellegéből adódóan gyorsnak és költséghatékonynak kell lennie. Hazánkban az elmúlt években történtek erőfeszítések a sürgősségi szédülésdiagnosztika hatékonyságának növelésére: 2011-ben Szirmai a részletes otoneurológiai vizsgálatra szoruló betegek előzetes kiválasztására hat pontból álló kérdőívet javasolt [3]. Varga és mtsai 2014-ben a részletes anamnézisfelvételt és a célzott neurológiai vizsgálat elvégzését tartották leghasznosabbnak a szédülés diagnózisának felállításában [1]. Tamás és mtsai 2016-ban egy új, IA evidenciájú, a szemmozgások analízisén alapuló vizsgálóeljárásról számoltak be, az izolált szédüléssel jelentkező veszélyes hátsóscala-területi stroke és a benignus, belsőfül eredetû szédülések gyors, ágy melletti differenciáldiagnosztikája céljából [4]. Büki 2017-ben könyvfejezetben foglalta össze a sürgősségi szédülésdiagnosztika feladatait és bizonyítékon alapuló új, ágy melletti vizsgálómódszereit [5]. Ugyancsak 2017-ben Nagy a célzott anamnézisfelvételre és az ágy melletti vizsgála- 
tok fontosságára hívta fel a figyelmet a sürgősségi vizsgálatok során [6].

A hazánkban és más országokban végzett tanulmányok eredményei azonban azt mutatják, hogy a szédüléses kórképek differenciáldiagnosztikája és adekvát ellátása az SBO-kon napjainkban nem optimális. A betegágy mellett gyorsan elvégezhető és a diagnózis felállításában alapvetően szerepet játszó fizikális vizsgálómódszerek a gyakorlatban még nem terjedtek el kellőképpen, és értékelésük is gyakran helytelen. A győri SBO-n végzett felmérésben a szédüléssel járó esetek 33,9\%-ában csak tüneti diagnózis született, annak ellenére, hogy az esetek 45,1\%-ában szakorvosi konzílium (97\%-ban neurológiai) is történt [2]. Hasonlóan magasnak, 22\%-osnak mutatkozott a tüneti diagnózisok aránya egy, az Amerikai Egyesült Államokban végzett felmérésben [7]. A győri SBO-n végzett vizsgálatban a szédülő betegek csupán 35,2\%-ában írtak le nystagmust [2], a Dix-Hallpike-manővert az esetek 31,5\%-ában, az Amerikai Egyesült Államokban az esetek 5,2\%-ában alkalmazták [7]. A szédülésdiagnosztika hatékonyságának javítása fontos, mert a pontos diagnózis felállításának elmaradása maradandó egészségkárosodáshoz vagy a panaszok krónikussá válásához vezethet.

A szédülés hátterében állhat benignus, perifériás vestibularis kórkép és potenciálisan életet fenyegető, akut beavatkozást igénylő kórállapot is, amelyek átfedő klinikai megjelenést mutathatnak, elkülönítésük azonban prognosztikai szempontból alapvető fontosságú. Akut vestibularis szindrómának (AVS) nevezzük az akut kezdetú, legalább 24 órán át folytonosan fennálló szédülés jelentkezését, amelyet hányinger, hányás, járásbizonytalanság, a fejmozgásokkal szembeni intolerancia kísér, továbbá a betegnek nystagmusa van. Izolált AVS-ről beszélünk, ha a betegnek a nystagmuson kívül nincs más neurológiai nyilvánvaló kórjele. A vertebrobasilaris (VB) területi stroke-ok jelentős hányada izolált AVS képében jelentkezik. Ekkor a betegnek csak finom oculomotoros és vestibulocochlearis tünetei vannak, és a kép a vestibularis neuritis klinikai megjelenését utánozza. Az izolált AVS képében jelentkező perifériás és centrális vestibularis kórképek elkülönítésére az úgynevezett HINTS-paradigmát dolgozták ki, amely magas specificitású és szenzitivitású, és 1A evidenciaszintű. A HINTS három oculomotoros tesztet foglal magába: 1. fejimpulzusteszt (head impulse test), 2. nystagmus vizsgálata, 3. a vertikális szemtengely-deviáció vizsgálata (test of skew), amely kiegészül a hallásvizsgálattal (HINTS plusz: akut halláscsökkenés detektálása) $[8,9]$. Centrális kórképre utal, ha a beteg fejimpulzustesztje negatív és/vagy nystagmusa centrális típusú, és/vagy skew deviációja van, és/vagy akut halláscsökkenése alakult ki. A patológia következtében megváltozó vestibuloocularis múködést a HINTS plusz paradigma azonnal érzékenyen detektálja. A koponyaCT-vizsgálat hátsóscala-területi kis infarktus kimutatására nem alkalmas, a mágneses rezonanciás képalkotás (MRI) a nagyon korai stádiumú VB-stroke-ot még nem detektálja, és az akut ellátásban elérhetősége korlátozott, költséges [8]. A HINTS-teszt szenzitivitása a stroke kizárására a tünetek kezdetétől számított első 48 órán belül meghaladja a diffúziósúlyozott (DWI) mágneses rezonanciás képalkotás (MRI) mérését [8]. A HINTS plusz teszt segítségével a potenciálisan életveszélyes centrális laesio és a perifériás vestibularis patológia biztonsággal elkülöníthető, amely megkönnyíti egy terápiás terv felállítását, lerövidíti a hospitalizáció idejét, és jelentôsen csökkenti a diagnosztikai és kezelési költségeket.

A fizikális vizsgálattal elvégzett HINTS plusz teszt eszközös vizsgálómódszerekkel is kivitelezhető, ezzel eredménye kvantifikálható [10]. Jelenleg nemzetközi klinikai kutatások zajlanak, amelyek a kvantifikált HINTS plusz teszt szenzitivitását és specificitását vizsgálják az izolált szédüléssel jelentkező hátsóscala-stroke-ok gyors diagnosztikájában. A fej- és a szemmozgások detektálására alkalmas videookulográfiás (VOG) szemüveggel a paradigma okulomotoros komponensei mérhetőek, audiometria végzésével pedig a hallásélesség kvantitatív vizsgálata lehetséges.

\section{Célkitüzés}

Vizsgálatunkkal a sürgősségi betegellátásban előforduló AVS-eket tanulmányoztuk különböző diagnosztikai módszerekkel. Arra kerestük a választ, hogy a perifériás és centrális vestibularis kórképek elkülönítésében milyen hatékonyságú a fizikális vizsgálattal és a kvantitatív műszeres vizsgálattal kivitelezett HINTS plusz paradigma, valamint a koponya képalkotó (MRI vagy $\mathrm{CT}$ ) vizsgálat. Vizsgáltuk továbbá azt, hogy AVS-sel járó hátsóscala-területi stroke esetében milyen arányban fordul elő csak izolált szédüléssel járó AVS.

\section{Betegek és módszer}

A kutatást a Petz Aladár Megyei Oktató Kórház Regionális Tudományos és Kutatásetikai Bizottsága engedélyezte. Etikai engedély száma: 76-1-23/2016.

A vizsgálatba olyan betegeket vontunk be, akik a győri Petz Aladár Megyei Oktató Kórház SBO-ján 2016. március 1. és 2017. március 1. között AVS miatt részesültek ellátásban. AVS-t állapítottunk meg, ha a betegnek 24 órán túl, de kevesebb, mint hét napja fennálló szédülése volt hányinger és/vagy hányás, járásbizonytalanság kíséretében, panaszaikat testhelyzet-változtatás fokozta, és nystagmusa volt. Izolált AVS-t véleményeztünk, ha AVS állt fenn és a betegnek a nystagmuson kívül egyéb nyilvánvaló neurológiai gócjele nem volt. Kizáró tényező volt, ha a betegnek korábbról ismert vestibularis vagy oculomotoros rendellenessége volt, alkohol- vagy drogintoxikáció alatt állt, vagy friss nyaki gerinctraumát szenvedett el. A beválasztott betegek részletes tájékoztatást követően beleegyező nyilatkozatot adtak.

$\mathrm{Az}$ anamnézisfelvételnél a sürgősségi szédülésdiagnosztikára kidolgozott $5 \mathrm{~T}$ (triage - timing - trigger - 
targeted examination - test) módszert használtuk [11], amely során regisztráltuk a szédülés fennállásának időtartamát és időbeli lefolyását, a szédülést kiváltó vagy fokozó tényezőket és a szédüléshez társuló panaszokat. Minden betegnél neurológus szakorvos (M. A.) rögzítette a neurológiai, fül-orr-gégész szakorvos (T. T. L.) a fül-orrgégészeti fizikális státuszt.

Minden betegnél a fizikális vizsgálat részeként elvégeztük a fizikális HINTS plusz tesztet:

1. A fejimpulzusteszt végzése során a beteg egyenesen előre tekintve a vizsgáló orrát fixálta, mialatt a vizsgáló a fejét hirtelen, váratlanul körülbelül 10 fokkal random jobbra és balra mozdította. A vizsgálat során regisztráltuk, hogy a beteg képes volt-e fixálni vagy végzett-e kompenzatoros saccadot (overt saccad).

2. Megvizsgáltuk, hogy a betegnek van-e spontán vagy tekintésirányú nystagmusa. A beteg fixációját Frenzel-szemüveg használatával küszöböltük ki.

3. A vertikális korrekciós szemmozgás (skew deviáció) jelenlétét az alternáló takarási teszttel vizsgáltuk, amely során a vizsgáló a beteg szemét három másodpercenként felváltva takarta le, mialatt a beteg a vizsgáló orrát fixálta. $\mathrm{Az}$ alternáló takarási tesztet 10 alkalommal ismételtük meg, és regisztráltuk az esetleges vertikális szemelmozdulást.

4. Előzetes otoszkópiát és szükség szerinti cerumeneltávolítást követően súgott beszéddel vizsgáltuk a beteg hallásélességét és Weber-tesztet végeztünk C5-ös hangvilla segítségével.

Minden betegnél elvégeztük a HINTS plusz teszt objektív, múszeres vizsgálatát is (minden esetben T. T. L. végezte). A fejimpulzusteszt, a nystagmus és a skew deviáció vizsgálatát a fej- és a szemmozgásokat szimultán regisztráló hordozható, ultrakönnyű VOG-szemüveggel végeztük (ICS Impulse, GN Otometrics, Taastrup, Dánia).

Video-fejimpulzusteszttel mind a hat félkörös ívjárat vestibuloocularis reflexét (VOR) vizsgáltuk. A VOGszemüveget az ülő vagy fekvő pozíciójú beteg fején szorosan rögzítettük, hogy a gyors fejmozgások közben megakadályozzuk az eszköz elmozdulását. A fejimpulzusteszt alatt a beteg a szemétól $120 \mathrm{~cm}$-re a falon elhelyezett vizuális célpontot fixált. A horizontális ivjáratok vizsgálata során a beteg mögött álló vizsgáló a beteg fejét 30 fokban előredöntve azon minimum 20 alkalommal, horizontális síkú, random irányú (jobbra vagy balra), váratlan, 10-20 fokos amplitúdójú, nagy sebességü (100$300 \mathrm{fok} / \mathrm{sze} k u n d u m)$ és nagy gyorsulású (3000-4000 fok/szekundum ${ }^{2}$ ) impulzusokat végzett. A VOG-szemüveg az adott félkörös ívjárat síkjában végzett gyors fejimpulzusok során detektálja a fej-és szemmozgások sebességét és irányát a fejimpulzus után 40, 60 és 80 milliszekundum múlva, és ezeket átlagolja. A fej és a szemek elfordulási sebességének hányadosa adja a VOR gainjét, amely a VOR hatásfokát fejezi ki. A gain értéke normális esetben a horizontális ívjáratok esetén $>0,79$, a vertikális ívjáratok esetén >0,69. A VOG-szemüveg USB-kábelen keresztül számítógéphez csatlakoztatható, amelyen futó szoftver (Otosuite Vestibular Software Version 4.0 Build 310) a nem megfelelően kivitelezett fejfordítások eredményeit törli, a megfelelően kivitelezett fejimpulzusok detektált adataiból kiszámítja az ívjárat VOR-jának átlag gainjét. A VOG-szemüveg detektálja a fejimpulzusteszt során előforduló korrekciós szemmozgásokat is. Covert saccadnak nevezzük a fejmozgás befejezése előtt jelentkező kompenzátoros refixációt, amely a fizikális fejimpulzusteszt során szabad szemmel nem látható. Az overt saccad a fejmozgás befejezése után jelentkező refixáció, amely észlelhető a fizikális vizsgálat során is. A beteg fejét 45 fokban jobbra fordítva a bal anterior-jobb posterior ívjáratok síkjában (LARP), 45 fokban balra fordítva a jobb anterior-bal posterior ívjáratok síkjában (RALP) is elvégeztük a fejimpulzustesztet. Regisztráltuk a vertikális ívjáratok VORjának gainjét és az overt és covert refixációs saccadok előfordulását.

A nystagmus vizsgálatakor $10 \mathrm{~cm}$-re a beteg szeme elé helyezett fehér papírlappal gátoltuk a vizuális fixációt. Az előre tekintő betegnél a VOG-szemüveg segítségével 30 másodpercen keresztül vizsgáltuk a spontán nystagmus előfordulását. Ezután 30 másodperces jobbra, balra, felfelé és lefelé tekintésnél a tekintésirányú nystagmus előfordulását vizsgáltuk meg. Centrális típusú nystagmusnak a horizontális síkban tekintésirányú vagy vertikálisan lefelé vagy felfelé csapó, illetve rotátoros nystagmust véleményeztünk, amelynek az amplitúdója és frekvenciája a vizuális fixáció gátlására nem csökkent. Perifériás típusú nystagmust véleményeztünk, ha horizontorotátoros, egy irányba csapó, fixációgátlásra frekvencia- és amplitúdónövekedést mutató szemtekerezgést észleltünk.

A skew deviációt az alternáló takarási teszttel vizsgáltuk. A beteg a szemétől $120 \mathrm{~cm}$-re elhelyezett pontra fixált. Kórosnak tekintettük a skew deviációt, ha a horizontális síkból a szem vertikális irányú kitérése 1 foknál nagyobb volt. Ez az érték 1,75 prizmadioptriánál nagyobb eltérésnek felel meg. A vertikális irányú skew deviáció vizsgálatát kétes esetekben vertikális irányú optikai prizmasorozattal is elvégeztük.

Minden betegnél az akut halláscsökkenés mértékének detektálására tisztahang-küszöb audiometriát végeztünk (Interacustics A/S DK 5610Assens, version DA931 audiométer).

Akut halláscsökkenést akkor véleményeztünk, ha három napon belül alakult ki olyan féloldali nagyothallás, amelynél három szomszédos audiometriás frekvencián 30 dB küszöbemelkedés volt kimutatható.

Centrális kórképet diagnosztizáltunk, ha a fejimpulzusteszt negatív volt és/vagy centrális típusú nystagmust észleltünk, és/vagy skew deviációt detektáltunk, és/vagy akut halláscsökkenés alakult ki. Negatívnak, azaz nem kórosnak tekintettük a klinikai fejimpulzustesztet, amennyiben a horizontális ívjáratok síkjában végezve a nagy sebességü, váratlan fejfordítást a beteg változatlanul a vizsgáló orrára fixált és nem észleltünk refixációs saccadot. Pozitívnak, azaz patológiásnak tekintettük a klinikai 
fejimpulzustesztet, amennyiben az előző vizsgálat során a szemek a fejfordítás irányába elfordultak, majd egy refixációs saccaddal tértek vissza a célpontra. A VOGszemüveggel végzett mérések kapcsán negatívnak tekintettük a fejimpulzusteszt eredményét, amennyiben refixációs saccadokat nem észleltünk és a VOR gain értéke normális esetben a horizontális ívjáratok esetén $>0,79$, a vertikális ívjáratok esetén >0,69. A VOG-szemüveggel kórosnak tekintettük a fejimpulzusteszt eredményét, ha refixációs saccadokat észleltünk és a VOR gain értéke normális esetben a horizontális ívjáratok esetén $<0,79$, a vertikális ívjáratok esetén $<0,69$. Az arteria cerebellaris posterior inferior (PICA) ellátási területébe eső stroke-ot véleményeztünk, ha a beteg horizontális síkban végzett fejimpulzustesztje mindkét irányba fiziológiás volt. AICA területi stroke-ot diagnosztizáltunk, amennyiben a betegnek tekintésirányú nystagmusa és/vagy vertikális skew deviációja és/vagy akut halláscsökkenése volt és a halláscsökkenése mellett az azonos oldali horizontális síkban elvégzett fejimpulzusteszt patológiás volt.

Minden betegnél az SBO-on akutan natív koponyaCT-vizsgálat történt, axiális síkban a koponyatető és a koponyaalap közötti területen, spirál üzemmódban, 3 mm szeletvastagsággal. Azoknál a betegeknél, akiknél a múszeres HINTS plusz vizsgálati metodikával centrális laesiót diagnosztizáltunk, további képalkotó vizsgálat történt. Tíz esetben 3 tesla (T) térerejú, 14 esetben 1,5 T térerejü szkennerrel koponya-MR és MR-angiográfiás vizsgálatot végeztünk. Az 1,5 T térerejü $\mathrm{MR}$-vizsgálatok Philips Multiva készülékkel axiális T2 TSE, DWI, 3D FLAIR, sagittalis T1 SE, T2* az MR-angiográfia 3D TOF ANGIO, illetve 3D PCA VEN beállítási paraméterekkel történtek kórházunk radiológiai osztályán. A $3 \mathrm{~T}$ térerejű MR-vizsgálatok Philips 3T Achieva szkennerrel axiális T2 TSE, FLAIR, DWI, T2 FFE, az MR-angiográfiás vizsgálatok $3 \mathrm{D}$ inflow/a, 3D PCA/v, 3D PCA/a-v, sagittalis Tl 3D TFE és kontrasztanyagos sagittalis 3D TFE beállítási paraméterekkel történtek a szombathelyi Markusovszky Egyetemi Oktató Kórház Radiológiai Osztályán. Két esetben vertebralis Doppler-ultrahangvizsgálat igazolta az arteria vetrebralis okklúziót, Philips CX 50 ultrahangkészülékkel, L12-3 linear array transzducerrel. Ha a HINTS plusz vizsgálati metodikával a beteg panaszai perifériás vestibularis eredetűnek bizonyultak és akut középfülgyulladáshoz társuló labyrinthitis állt fenn, közép- és belsőfül-HR-CT-vizsgálatra került sor 1 mm-es rétegvastagsággal, spirál üzemmódban.

Traumás eredetű AVS esetén a koponyabázis-fracturák kizárására először koponya-CT-vizsgálat történt, axiális síkban a koponyatetó és a koponyaalap közötti területen, spirál üzemmódban, 3 mm szeletvastagsággal, majd a lelet birtokában végeztük el a HINTS plusz vizsgálatot. A vestibularis neuronitisnek diagnosztizált esetekben további képalkotó diagnosztikára a betegeket nem küldtük, de minden betegnél előzetesen már koponya-CTvizsgálat történt az SBO-on elfogadott kivizsgálási protokollnak megfelelően.

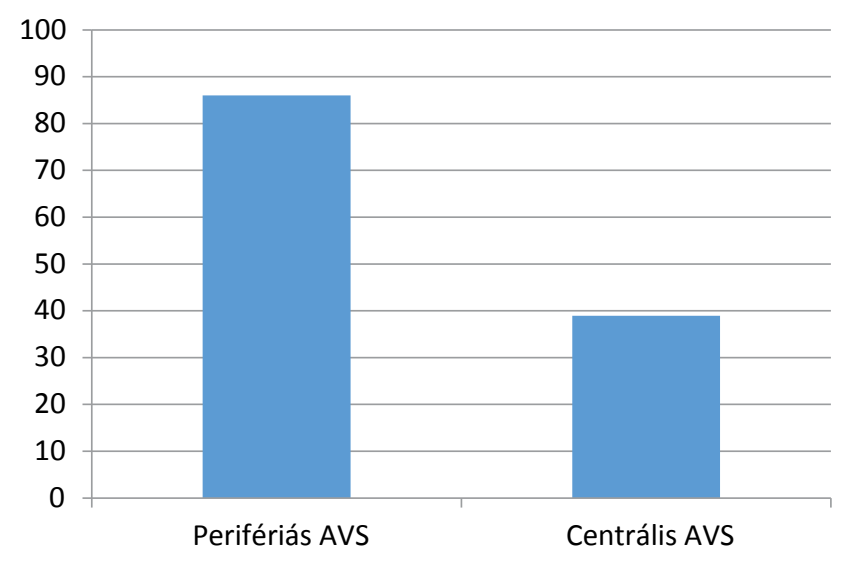

1. ábra

A perifériás és a centrális akut vestibularis szindrómák (AVS) száma a műszeres HINTS plusz vizsgálat eredményei alapján (125 beteg)

AVS $=$ akut vestibularis szindróma; HINTS-teszt $=($ head $\mathrm{im}-$ pulse test) fejimpulzusteszt, (direction-changing nystagmus) irányváltó nystagmus, (test of skew deviation) a skew deviáció vizsgálata

\section{Eredmények}

A vizsgálatba 125 beteget vontunk be, akik közül 62 $(49,2 \%)$ volt nő. Életkoruk 18-88 év között mozgott, az átlagéletkor 53 év volt.

A fizikális HINTS plusz vizsgálattal 72 esetben perifériás, 53 esetben centrális típusú AVS-t diagnosztizáltunk. A műszeres HINTS plusz vizsgálattal 86 esetben (69\%) perifériás, $39(31,0 \%)$ esetben centrális eredetet állapítottunk meg (1. ábra). A fizikális és a müszeres HINTS plusz vizsgálat eltérő adatai közötti eltérés magyarázata az, hogy a múszer nélküli vizsgálat során csak a horizontális ívjárat síkjában végeztük el a fejimpulzustesztet, ezért tévesen stroke-nak véleményeztünk kilenc, csak az alsó idegágat érintő perifériás neuronitis vestibularist, ahol a VOR gain csökkenése izoláltan csak a jobb vagy a bal oldali hátsó ívjáratot érintette.

Covert saccadot (a fejimpulzusteszt lezajlása közben kialakuló saccad, amely kisebb, mint 2 fok szögeltérésü,

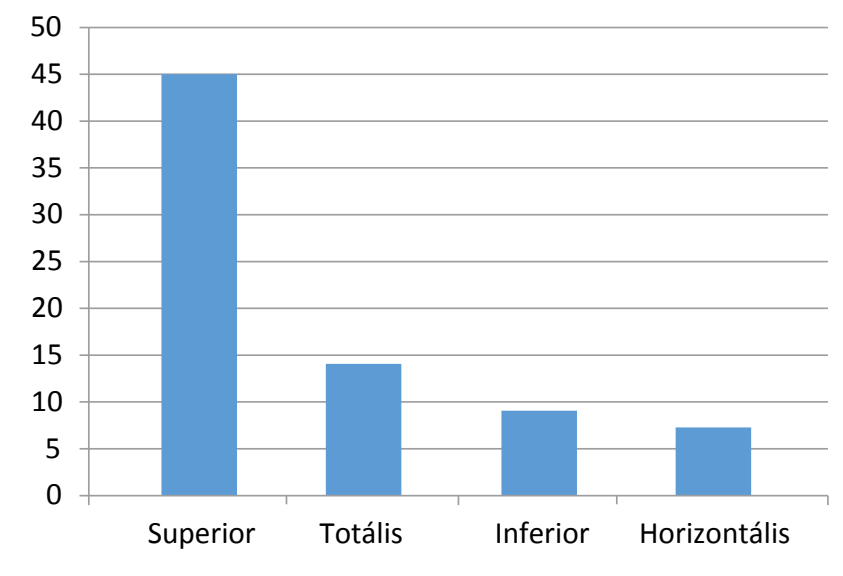

2. ábra $\mid$ A vestibularis neuritisszel diagnosztizált betegek száma a különböző idegágak érintettségének a függvényében ( 75 beteg) 
így a vizsgáló számára észrevehetetlen) derített fel a VOG-szemüveg öt további betegnél. Ezeknél a betegeknél a fizikális HINTS plusz vizsgálat alkalmával tévesen stroke-ot véleményeztünk.

A perifériás AVS-ek közül 75/86 (87,2\%) betegnél vestibularis neuritist, $9 / 86(10,5 \%)$ betegnél fülészeti szövődmény következtében kialakult labyrinthitist, 2/86
$(2,3 \%)$ betegnél piramiscsonttörés után kialakult akut labyrinthlaesiót diagnosztizáltunk. A vestibularis neuritiszszel diagnosztizált betegek $60 \%$-ában $(45 / 75)$ a nervus vestibularis felső, 18\%-ában (14/75) a felső és alsó, 12\%ában $(9 / 75)$ izoláltan az alsó idegág károsodását észleltük. A betegek $9 \%$-ánál $(7 / 75)$ izolált horizontális ívjárati múködéscsökkenést detektáltunk (2. ábra).

1. táblázat |A múszeres HINTS plusz vizsgálat alapján izolált és neurológiai kísérő tünetekkel jelentkező PICA-területi stroke-nak diagnosztizált eseteink

\begin{tabular}{|c|c|c|c|c|c|c|c|c|}
\hline Sorszám & Nem & Életkor & Vhit & $\begin{array}{l}\text { Centrális } \\
\text { nystagmus }\end{array}$ & $\begin{array}{c}\text { Skew } \\
\text { deviáció }\end{array}$ & $\begin{array}{l}\text { Akut halláscsök- } \\
\text { kenés }\end{array}$ & Képalkotó vizsgálat & Neurológiai kísérő tünet \\
\hline 6. & Nő & 61 & - & - & - & - & $\begin{array}{l}\text { Koponya-MR: } \\
\text { friss stroke }\end{array}$ & Dysarthria \\
\hline 9. & Férfi & 44 & - & - & - & - & Nem készült & Diplopia \\
\hline 13. & Nő & 81 & - & + & - & - & $\begin{array}{c}\text { Vertebralis } \\
\text { DUH: arteria vertebralis } \\
\text { okklúzió }\end{array}$ & Diplopia, dropattak \\
\hline 17. & Férfi & 75 & - & - & + & - & $\begin{array}{c}\text { Koponya-CT: } \\
\text { friss stroke }\end{array}$ & Dysaesthesia (arc) \\
\hline 19. & Férfi & 74 & - & + & - & - & Nem készültt & Diplopia \\
\hline 25 & Nő & 49 & - & - & - & - & $\begin{array}{l}\text { Koponya-MR: } \\
\text { friss stroke }\end{array}$ & Dysaesthesia (arc) \\
\hline 27. & Nő & 75 & - & - & - & - & $\begin{array}{c}\text { Vertebralis } \\
\text { DUH: } \\
\text { arteria vertebralis okklúzió }\end{array}$ & Dysaesthesia (arc) \\
\hline 32. & Férfi & 64 & - & - & - & - & $\begin{array}{l}\text { Koponya-CT: } \\
\text { friss stroke }\end{array}$ & Felső végtag paresise \\
\hline 37. & Nő & 65 & - & + & - & - & $\begin{array}{l}\text { Koponya-CT: } \\
\text { friss stroke }\end{array}$ & Horner-szindróma \\
\hline 41. & Férfi & 55 & - & + & - & - & $\begin{array}{l}\text { Koponya-CT: } \\
\text { negatív }\end{array}$ & $\begin{array}{l}\text { Internukleáris } \\
\text { ophtalmoplegia }\end{array}$ \\
\hline 1. & Nő & 71 & - & + & - & - & $\begin{array}{l}\text { Koponya-MR: } \\
\text { kisérbetegség }\end{array}$ & - \\
\hline 2. & Nő & 69 & - & - & - & - & $\begin{array}{l}\text { Koponya-MR: } \\
\text { friss stroke }\end{array}$ & - \\
\hline 5. & Nő & 85 & - & - & - & - & $\begin{array}{l}\text { Koponya-MR: } \\
\text { friss stroke }\end{array}$ & - \\
\hline 8. & Nő & 77 & - & - & - & - & $\begin{array}{l}\text { Koponya-CT: } \\
\text { friss stroke }\end{array}$ & - \\
\hline 10 & Férfi & 60 & - & - & - & - & $\begin{array}{l}\text { Koponya-MR: } \\
\text { kisérbetegség }\end{array}$ & - \\
\hline 20 & Nő & 69 & - & - & - & - & $\begin{array}{l}\text { Koponya-MR: } \\
\text { kisérbetegség }\end{array}$ & - \\
\hline 22 & Férfi & 50 & - & - & - & - & $\begin{array}{l}\text { Koponya-MR: } \\
\text { kisérbetegség }\end{array}$ & - \\
\hline 23 & Nő & 70 & - & + & - & - & $\begin{array}{l}\text { Koponya-MR: } \\
\text { kisérbetegség }\end{array}$ & - \\
\hline 29. & Nő & 58 & - & - & - & - & $\begin{array}{l}\text { Koponya MR: } \\
\text { friss stroke }\end{array}$ & - \\
\hline 31. & Nő & 60 & - & - & + & - & $\begin{array}{l}\text { Koponya-MR: } \\
\text { kisérbetegség }\end{array}$ & - \\
\hline 36. & Nő & 76 & - & - & - & - & $\begin{array}{l}\text { Koponya-MR: } \\
\text { friss stroke }\end{array}$ & - \\
\hline
\end{tabular}

$\mathrm{CT}=$ komputertomográfia; $\mathrm{DUH}=$ vertebralis Doppler-ultrahangvizsgálat; $\mathrm{MR}=$ mágneses rezonanciás képalkotás; PICA = arteria cerebelli inferior posterior; Vhit = fejimpulzusteszt 
2. táblázat $\mid$ A múszeres HINTS plusz vizsgálattal AICA-területi stroke-nak diagnosztizált, neurológiai kísérő tünetekkel és izolált szédüléssel jelentkező hátsóscala-stroke-eseteink

\begin{tabular}{|c|c|c|c|c|c|c|c|c|}
\hline Sorszám & Nem & Életkor & Vhit & $\begin{array}{l}\text { Centrális } \\
\text { nystagmus }\end{array}$ & $\begin{array}{c}\text { Skew } \\
\text { deviáció }\end{array}$ & $\begin{array}{c}\text { Akut } \\
\text { halláscsökkenés }\end{array}$ & Képalkotó eljárás & Neurológiai kíséró tünet \\
\hline 4. & Férfi & 40 & Pozitív & - & - & + & $\begin{array}{l}\text { Koponya-MR: } \\
\text { friss stroke }\end{array}$ & $\begin{array}{c}\text { Dysaesthesia } \\
(\operatorname{arc})\end{array}$ \\
\hline 12 & Férfi & 55 & Pozitív & - & - & + & $\begin{array}{l}\text { Koponya-MR: } \\
\text { friss stroke }\end{array}$ & Diplopia, facialis paresis \\
\hline 14. & Nő & 72 & Pozitív & - & + & - & $\begin{array}{l}\text { Koponya-CT: } \\
\text { friss stroke }\end{array}$ & Pozitív Babinski-jel \\
\hline 18. & Férfi & 72 & Pozitív & - & + & - & $\begin{array}{l}\text { Koponya-MR: } \\
\text { friss stroke }\end{array}$ & $\begin{array}{l}\text { Dysaesthesia } \\
\text { (felső végtag) }\end{array}$ \\
\hline 28. & Nő & 61 & Pozitív & + & + & + & $\begin{array}{l}\text { Koponya-MR: } \\
\text { kisérbetegség }\end{array}$ & $\begin{array}{l}\text { Dysaesthesia } \\
(\operatorname{arc})\end{array}$ \\
\hline 3. & Férfi & 70 & Pozitív & - & - & + & $\begin{array}{l}\text { Koponya-MR: } \\
\text { kisérbetegség }\end{array}$ & - \\
\hline 7. & Nő & 55 & Pozitív & - & - & + & $\begin{array}{l}\text { Koponya-MR: } \\
\text { negatív }\end{array}$ & - \\
\hline 11. & Nő & 55 & Negatív & + & - & + & $\begin{array}{l}\text { Koponya-MR: } \\
\text { negatív }\end{array}$ & - \\
\hline 15. & Nő & 51 & Pozitív & - & + & - & $\begin{array}{l}\text { Koponya-MR: } \\
\text { negatív }\end{array}$ & - \\
\hline 16. & Nő & 81 & Pozitív & - & + & - & $\begin{array}{l}\text { Koponya-MR: } \\
\text { kisérbetegség }\end{array}$ & - \\
\hline 21. & Nő & 76 & Pozitív & - & + & - & $\begin{array}{l}\text { Koponya-MR: } \\
\text { kisérbetegség }\end{array}$ & - \\
\hline 24. & Nő & 60 & Pozitív & + & - & - & $\begin{array}{l}\text { Koponya-MR: } \\
\text { kisérbetegség }\end{array}$ & - \\
\hline 26. & Nő & 60 & Pozitív & - & - & - & $\begin{array}{l}\text { Koponya-CT: } \\
\text { negatív }\end{array}$ & - \\
\hline 33. & Nő & 76 & Pozitív & - & - & + & $\begin{array}{l}\text { Koponya-CT: } \\
\text { negatív }\end{array}$ & - \\
\hline 30. & Férfi & 71 & Pozitív & - & - & + & $\begin{array}{l}\text { Koponya-CT: } \\
\text { friss stroke }\end{array}$ & - \\
\hline 34. & Nő & 79 & Pozitív & + & - & + & $\begin{array}{l}\text { Koponya-MR: } \\
\text { negatív }\end{array}$ & - \\
\hline 35. & Nő & 69 & Pozitív & + & - & + & $\begin{array}{l}\text { Koponya-CT: } \\
\text { negatív }\end{array}$ & - \\
\hline
\end{tabular}

$\mathrm{AICA}=$ arteria cerebelli inferior anterior; $\mathrm{CT}=$ komputertomográfia $; \mathrm{MR}=$ mágneses rezonanciás képalkotás; Vhit $=$ fejimpulzusteszt

A centrális AVS-ek közül 38 esetben hátsóscala-területi stroke-ot, egy esetben agytörzsi encephalitist diagnosztizáltunk.

A hátsóscala-területi stroke-ok közül a múszeres HINTS plusz vizsgálattal 21/38 (55,3\%) esetben véleményeztünk PICA-területi stroke-ot. A horizontális síkú fejimpulzusteszt minden beteg esetében normális gainértéket mutatott. Centrális típusú nystagmust detektáltunk $6 / 21$ esetben $(28,6 \%)$, skew deviációt $2 / 21$ esetben $(9,5 \%)$. Egyik betegnek sem volt akut halláscsökkenése. A PICA-területi stroke-ok közül izolált AVS volt észlelhető $11 / 21 \quad(52,4 \%)$ esetben. Közülük 5/11 $(45,5 \%)$ esetben a képalkotó eljárások is igazolták a friss hátsóscala-területi stroke-ot (három esetben 1,5 T MRI, egy esetben 3 T MRI, egy esetben koponya-CT). Hat esetben az elvégzett képalkotó vizsgálatok nem mutattak stroke-ra utaló patológiát. A nystagmuson kívül más neurológiai kórjelet is okozó PICA-területi stroke-ok (10/21, 47,6\%) esetében a leggyakoribb neurológiai kísérő tünet az azonos oldali arc érzészavara volt $(4 / 10$ beteg). A képalkotó vizsgálatok $7 / 10$ betegnél igazolták a friss hátsóscala-stroke-ot (két esetben 1,5 T MRI, három esetben koponya-CT). További két esetben a nyaki erek duplex ultrahangvizsgálata az arteria vertebralis okklúzióját ábrázolta. Három esetben a képalkotó vizsgálatok nem mutattak stroke-ra utaló patológiát (1. táblázat).

A mûszeres HINTS plusz vizsgálati módszer segítségével 17/38 (44,7\%) esetben AICA-területi stroke diagnózisát állítottuk fel. Közülük 12/17 (70,6\%) esetben a 
A fejimpulzusteszt, a centrális nystagmus, a skew deviáció és az akut halláscsökkenés százalékos aránya a múszeres HINTS plusz módszerrel detektált PICA- és AICA-stroke-ok esetén

\begin{tabular}{lcccc}
\hline & $\begin{array}{c}\text { HIT-pozitív } \\
(\%)\end{array}$ & $\begin{array}{c}\text { Centrális } \\
\text { nystagmus } \\
\text { van } \\
(\%)\end{array}$ & $\begin{array}{c}\text { Vertikális } \\
\text { skew } \\
\text { deviáció } \\
\text { van } \\
(\%)\end{array}$ & $\begin{array}{c}\text { Akut } \\
\text { halláscsökke- } \\
\text { nés van } \\
(\%)\end{array}$ \\
\hline PICA-stroke & 0 & 27 & 8 & 0 \\
AICA-stroke & 94 & 29 & 35 & 59 \\
\hline
\end{tabular}

AICA: arteria cerebelli inferior anterior; HIT = (head impulse test) fejimpulzusteszt; PICA = arteria cerebelli inferior posterior

stroke izolált AVS képében lépett fel. A fejimpulzusteszt mind a 11 beteg esetében egyik oldalon patológiás volt, emellett $7 / 12$ betegnél akut halláscsökkenést, $4 / 12$ betegnél centrális típusú nystagmust, $3 / 12$ betegnél vertikális skew deviációt észleltünk. A képalkotó vizsgálatok csak egy esetben $(8,3 \%)$ igazolták a hátsóscala-területi stroke-ot. A nystagmuson kívül egyéb neurológiai kórjelet is okozó AICA-területi stroke diagnózisát 5/17 beteg esetében állítottuk fel. A leggyakoribb neurológiai kísérő tünet ebben a csoportban is az arc érzészavara volt $(2 / 5)$. Négy betegnél a képalkotó eljárás is igazolta a friss stroke-ot (két esetben $3 \mathrm{~T}$ MRI, egy esetben 1,5 T MRI, egy esetben koponya-CT) (2. táblázat).

A múszeres HINTS plusz vizsgálattal igazolt AICA-, illetve PICA-területi stroke-ok esetében (izolált szédüléssel járó esetek és a neurológiai kísérő tünetekkel járó esetek együttesen) a pozitív fejimpulzusteszt, centrális típusú nystagmus, vertikális skew deviáció és az akut halláscsökkenés százalékos arányát a 3. táblázatban foglaltuk össze.

A 125, AVS-sel diagnosztizált betegnél 124 esetben történt akut natív koponya-CT-vizsgálat. A koponyaCT-vizsgálat 6/124 (4,8\%) esetben ábrázolt ischaemiás stroke-ot, vérzéses stroke egy esetben sem igazolódott (3. ábra).

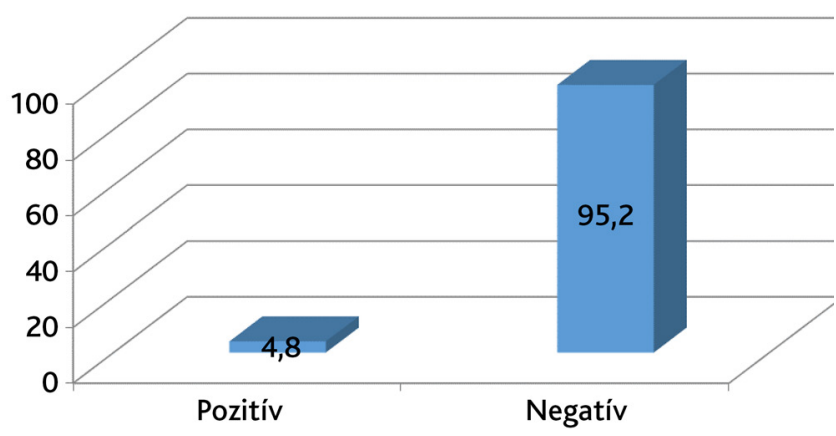

3. ábra $\quad$ A hátsóscala-stroke kizárása céljából az SBO-on indikált pozitív és negatív eredményú natív koponya-CT-k százalékos aránya $(125$ beteg $=100 \%)$

$\mathrm{CT}=$ komputertomográfia; $\mathrm{SBO}=$ sürgősségi betegellátó osztály

\section{Megbeszélés}

AVS-nek hívjuk az akut kezdetű, 24 órán túl fennálló szédülést, amelyet émelygés és hányás, egyensúlyzavar, a fejmozgásokkal szembeni intolerancia kísér, és a betegnek nystagmusa van [12]. AVS-t leggyakrabban vestibularis neuritis vagy vertebrobasilaris területi stroke okoz. Epidemiológiai felmérések szerint SBO-n a szédülő betegek 10-20\%-a jelentkezik AVS tüneteivel [13]. Az AVS-ek $25 \pm 15 \%$-a stroke következménye, és az ilyen esetekben a legújabb felmérések szerint az esetek 50\%ában nystagmuson kívül nem észlelhető egyéb nyilvánvaló neurológai kórjel [12]. Ez utóbbi eseteket hívjuk izolált AVS-nek, amelyek differenciáldiagnosztikai jelentőségét az adja, hogy összetéveszthető az eltérő ellátást igénylő vestibularis neuritisszel. Az izolált AVS-t okozó hátsóscala-területi stroke-ok felismerése alapvetően fontos, mert a megfelelő preventív terápia elmaradása a stroke ismétlődésének veszélyét hordozza magában, továbbá progresszív VB-stroke esetén megfelelő monitorozás és kezelés hiányában a kórfolyamat fatális kimenetelü is lehet [14]. A cerebellaris stroke-ok 10-20\%-ában az akut szakban térfoglaló hatású ödéma alakulhat ki, amely agytörzsi kompressziót és agykamra-elzáródást eredményezhet, következményes hydrocephalus kialakulásával. Agyödéma-képződésre a stroke kialakulásának első öt napja alatt kell számítani, a legsúlyosabb általában a harmadik napon [15]. Egy, az Amerikai Egyesült Államok SBO-in végzett vizsgálatban a centrális eredetü izolált AVS-ek (pseudoneuritisek) 35\%-ában mulasztották el a helyes diagnózist, míg ha az AVS-t más neurológiai kórjel is kíséri, a téves diagnózisok aránya 4\%-os [16]. AVS-ben stroke fennállására utal a hirtelen, váratlan kezdet [17], a hirtelen, intenzív, folyamatos craniocervicalis fájdalom [18], és a különböző tünetek közötti aránytalanság, például extrém törzsataxia, folyamatos hányás alig észrevehető nystagmus mellett [19]. VB-stroke-ban az esetek 29\%-ában találtak a megelőző hetekben jelentkező VB tranziens ischaemiás attakra (TIA) utaló visszatérő panaszokat [20]. Elsősorban VB-stroke-ra utal az is, ha hirtelen kezdetű szédüléshez halláscsökkenés is társul. Mivel a belső fül vérellátását az AICA egyik ága, az arteria labyrinthica adja, AICA-területi infarktusban egyszerre károsodhat a belső fül és a vestibularis magok keringése, amely kombinált centrális és perifériás vestibularis károsodást eredményezhet [21].

$\mathrm{Az}$ általunk végzett felmérésben az AVS-sel vizsgált betegek 99\%-ában végeztek a sürgősségi ellátás során koponya-CT-vizsgálatot, amely indokolatlanul magas arányú. Hasonlóan magas CT-vizsgálat-használati arányt találtak az Amerikai Egyesült Államok SBO-in és egy hazai SBO-n végzett felmérésben is [1]. Ezek az eredmények arra utalnak, hogy a sürgősségi betegellátás során a perifériás és centrális vestibularis kórképek elkülönítése a jelenlegi klinikai gyakorlatban még problematikus. Az akutan elvégzett koponya-CT-vizsgálattal elsősorban a vérzéses stroke detektálható, a tünetek kezdetétől számí- 
tott 24 órán belül az ischaemiás stroke még nem ábrázolódik. Vizsgálatunkban az elvégzett koponya-CT-vizsgálat 95,2\%-ban nem mutatott ki centrális laesiót. VB-stroke-ban a koponya-CT-vizsgálat diagnosztikai értéke az akut szakon túl is korlátozott, mert a hátsó scalai idegi struktúrákat körülvevő vastag koponyacsont radiográfiás mütermékképződés révén akadályozza az agytörzsi struktúrák értékelését. Hwang és mtsai a 30 órán belül végzett koponya-CT-vizsgálat szenzitivitását VB-stroke-ban 42\%-osnak találták [20]. A VB-stroke detektálásában az akutan végzett koponya-MR-vizsgálat érzékenysége a CT-vizsgálaténál jóval magasabb, azonban a legújabb vizsgálati eredmények szerint 48 órán belül elvégezve öt DWI-mérésból egy fals negatív eredményt ad [16].

Az utóbbi években az AVS differenciáldiagnosztikájára új, magas specificitású és szenzitivitású, ágy melletti teszteket fejlesztettek ki, amelyek már a tünetek jelentkezésének első óráiban is jeleznek, amikor a neuroradiológiai diagnosztika még nem megbízható vagy nem elérhető [8]. Ezek közül a tesztek közül kiemelkedő jelentőségû a VOR-t vizsgáló fejimpulzusteszt, szerzői nevén a Halmágyi-Curthoys-teszt, amely a szédülés egyik legfontosabb, ágy melletti diagnosztikai vizsgálatának tekinthető $[22,23]$. A fejimpulzusteszt során a beteg fejét a horizontális ívjáratok síkjában kis amplitúdóval és nagy sebességgel, passzívan elfordítjuk, miközben a beteg tekintetével egyenesen előre fixál. Fiziológiás müködésű VOR esetén a fej elmozdítását a szemek ellentétes irányú, azonos szögú elfordulása kíséri, amely révén a fixált környezeti célpont képe a retina foveájában rögzíthetó és a látott kép éles marad. Perifériás vestibularis laesióban a VOR elégtelen múködésü, ezért a károsodott oldal felé kivitelezett fejimpulzusteszt során a fej elfordulását nem kíséri a szemek azonnali reflexes ellenoldali elmozdulása. Ezt a beteg a vizuális célpont fixálását célzó, kis latenciával megjelenő saccad végzésével kompenzálja, amely a fejimpulzusteszt kivitelezése során jól megfigyelhető. A PICA és az arteria cerebelli superior területi infarktusokban a VOR múködése intakt marad, és a Halmágyi-Curthoys-teszt nem kóros. AICA-infarktusban az ischaemia együtt érintheti a belső fület és a vestibularis magvakat, ezáltal kombinált perifériás és centrális vestibularis károsodást okozhat [21]. Ebben az esetben a fejimpulzusteszt pozitív lehet, azonban egyéb finom oculomotoros eltérések jelenléte lehetővé teszi az elkülönítést a perifériás vestibularis laesiótól. Centrális vestibularis laesióra utal, ha a betegnek tekintésirányú nystagmusa van, vagy a centrális otolitpályák károsodása miatt vertikális skew deviáció alakul ki. A fenti három fizikális tesztet foglalja magába Kattah és mtsai által javasolt HINTSparadigma (head impulse, nystagmus, test of skew) [8]. A stroke lehetőségét jelző vizsgálati eredmények alapján a szerzők javasoltak egy második mozaikszót is: impulse normal vagy fast-phase alternating vagy refixation on cover test (INFARCT) [8]. VB-stroke-ban a HINTS vizsgálati paradigma szenzitivitását 100\%-nak, specificitását 96\%-osnak találták. Ezáltal az érzékenysége meghaladja a 24-48 órán belül végzett DWI MR-vizsgálatét. A 96\%os specificitás azt jelzi, hogy ritkán álpozitív esetek előfordulhatnak. Ennek egyik oka az, hogy rövid ideig (egy-két nap) vestibularis neuritis esetén is elöfordulhat skew deviáció [24]. Vestibularis neuritisben azonban ipsilateralis akut halláscsökkenés nem fordul elő, amely miatt a HINTS-vizsgálat kiegészítése a betegágy melletti fül- és hallásvizsgálattal (otoszkópia, hangvilla és súgott beszéd vizsgálata) HINTS plusz paradigmateszt specificitását 99\%-ra emeli [9]. A HINTS plusz vizsgálat nemcsak a 48 órán belül elvégzett DWI MRI, hanem a hagyományos, age, blood pressure, clinical features, duration of symptoms, diabetes $(\mathrm{ABCD} 2)$ rizikófaktorok jelenlétén alapuló vizsgálatok hatékonyságát is meghaladja a stroke vonatkozásában [9].

Vizsgálatunkban a kvantitatív, müszeres HINTS plusz módszerrel vizsgált AVS-es betegek kétharmadában perifériás, egyharmadában centrális vestibularis eredetet diagnosztizáltunk. Ez az adat nagyságrendileg megegyezik a bevezetőben említett nemzetközi vizsgálati eredményekkel.

A perifériás eredetű AVS-ek közül a leggyakoribb ok a vestibularis neuritis volt $(87,2 \%)$, amelyet az otogén szövődményes labyrinthitis $(10,5 \%)$ és traumás labyrinthsérülés követett $(2,3 \%)$. A vestibularis neuritises eseteken belül leggyakrabban $(60 \%)$ a nervus vestibularis felső ágának féloldali ledált múködését észleltük, amely a felső és oldalsó ívjáratok, valamint az utriculus idegi impulzusait továbbítja. Gyakoriságban mindkét (felső és alsó) idegág funkciókiesése következett be (18\%), és az esetek 12\%-ában izoláltan csak az alsó idegág laesióját detektáltuk. Az alsó idegág az alsó ívjárat és a sacculus beidegzését adja, és izolált funkciókiesésének felismerése fizikális vizsgálattal problémás. Ennek oka, hogy spontán nystagmus egyáltalán nem észlelhető vagy csak diszkrét ferdén lefelé ütő nystagmus látható torziós komponenssel, továbbá a horizontális síkban végzett fejimpulzusteszt fiziológiás, amely centrális laesio gyanúját jelzi. Ezekben az esetekben csak a VOG-szemüveggel a vertikális ívjáratok síkjában végzett video-fejimpulzusteszt segítségével mutatható ki a laesio. Érdekes módon - Büki megfigyeléseivel összhangban - 9\%-ban izolált horizontális ívjárati múködés csökkenését észleltük [25, 26]. A betegek utánkövetése során a múszeres HINTS plusz vizsgálattal vestibularis neuritisnek diagnosztizált esetekben a későbbiekben centrális kórképre nem derült fény, azaz álnegatív stroke-eset előfordulásáról nem tudunk. A kilenc betegünknél észlelt középfülgyulladás mellett kialakult labyrinthitis felhívja a figyelmet a fülészeti vizsgálatok fontosságára. Két betegünknél piramiscsonttörés okozta az AVS-t.

A múszeres HINTS plusz vizsgálattal centrálisnak diagnosztizált AVS-eken belül 22 esetben $(55,3 \%)$ a fiziológiás fejimpulzusteszt alapján PICA-területi infarktust véleményeztünk, amely esetek fele izolált AVS képében jelentkezett. Az izolált AVS képében és mind a hat ívjárat 
esetében fiziológiás fejimpulzusteszttel jelentkező esetek közül a képalkotó vizsgálatok öt esetben igazolták a PICA-területi stroke-ot. Hat esetben nem mutatkozott képalkotó vizsgálattal eltérés, ezek közül három esetben utólag vestibularis migrént véleményeztünk. A további három esetben, feltételezésünk szerint, a negatív MRIeredmény oka a vizsgálat elégtelen érzékenysége volt apró lacunaris méretü infarktus kimutatására (4. táblázat).

Sylaja és mtsai egy vizsgálatban a stroke-os páciensek 25\%-ánál negatív DWI-MR-vizsgálati eredményt észleltek [27]. Morita megállapításai szerint a hátsóscala-eredetú stroke-ok később okoznak DWI-MR-vizsgálattal észlelhető kóros eltérést, mint az elülsőscala-eredetú stroke-ok [28].

A múszeres HINTS plusz vizsgálat alapján 17 AICAterületi stroke-esetet diagnosztizáltunk, amely a VBstroke-esetek 44,7\%-a. Az esetek 70,6\%-a (12 beteg) izolált AVS képében jelentkezett. Ezekben az esetekben a horizontális síkú fejimpulzusteszt az egyik irányba patológiás volt, de a betegeknek egyéb centrális laesióra utaló oculomotoros tünetük (centrális nystagmus, skew deviáció) vagy halláscsökkenésük is volt. Ez utóbbi esetek közül mindössze egy betegnél volt infarktus kimutatható a képalkotó vizsgálat segítségével. Ennek egyik magyarázata lehet, hogy nem stroke, hanem virális labyrinthitis zajlott, elsősorban olyan betegek esetében, akiknél az anamnézisben recidiváló herpessimplex-vírusfertőzés fordult elő vagy a szédüléses panaszok jelentkezése előtt egyéb vírusfertőzés zajlott. A másik lehetséges magyarázat az, hogy izolált labyrinthstroke zajlott, amely az általunk használt képalkotó módszerekkel nem volt kimutatható. Elsősorban azoknál a betegeknél feltételeztük ez utóbbi kórokot, akiknél az ABCD2-kritériumoknak megfelelően több stroke-rizikófaktor is fennállt. A virális labyrinthitis versus labyrinthstrokeeredetről szóló vita kapcsán új adat, hogy a szervezetet érő herpes zoster fertőzés stroke-rizikófaktornak tekinthető (hazard ratio: 1,35), és a fertőzés kialakulása utáni egyéves időszakban és a 40 év alatti betegeknél fokozottabb a veszély [29].

A műszeres HINTS plusz vizsgálattal AICA-területi stroke-nak diagnosztizált eseteink 29,4\%-ában (öt beteg) neurológiai kísérő tüneteket is észleltünk. Ezek közül négy esetben a képalkotó vizsgálatok is igazolták a friss stroke-ot. Az izolált AVS képében jelentkező, AICA-területi stroke-nak diagnosztizált esetek utánkövetése során három esetben egyéb kórkép igazolódott: egy esetben Ménière-roham okozta az álpozitív vizsgálati eredményt, egy esetben vestibularis neuronitis, ahol a végállású nystagmust helytelenül ítéltük tekintésirányú nystagmusnak, egy esetben kiderült, hogy a skew deviáció évtizedek óta fennállt és a betegnek congenitalis nystagmusa volt (4. táblázat).

4. táblázat |Az eszközös és az eszköz nélküli HINTS plusz vizsgálatok összehasonlítása a stroke-álpozitivitás szempontjából

\begin{tabular}{|c|c|c|c|c|}
\hline \multirow[t]{2}{*}{ Vizsgálat típusa } & \multicolumn{3}{|c|}{ Betegek száma } & \multirow{2}{*}{$\begin{array}{l}\text { Álpozitív AVS-betegek diagnózisa és száma } \\
\text { és az álpozitivitás feltételezett oka }\end{array}$} \\
\hline & Perifériás AVS & $\begin{array}{l}\text { Centrális AVS } \\
\quad(\text { stroke })\end{array}$ & Álpozitív AVS & \\
\hline Fizikális HINTS plusz & 72 & 53 & 36 & $\begin{array}{l}{ }^{1} \text { Neuronitis vest. inf:: } 9 \\
{ }^{2} \text { Neuronitis vest. sup.: } 5 \\
{ }^{3} \text { Vestibularis migrén: } 3 \\
{ }^{4} \text { Virális labyrinthitis vs. labyrinthstroke: } 11 \\
{ }^{5} \text { Ménière-betegség: } 1 \\
{ }^{6} \text { Neuronitis vest. sup.: } 2 \\
{ }^{7} \text { Valószínú stroke: } 5\end{array}$ \\
\hline Eszközös HINTS plusz & 86 & 39 & 22 & $\begin{array}{l}{ }^{3} \text { Vestibularis migrén: } 3 \\
{ }^{4} \text { Virális labyrinthitis vs. labyrinthstroke: } 11 \\
{ }^{5} \text { Ménière-betegség: } 1 \\
{ }^{6} \text { Neuronitis vest. sup.: } 2 \\
{ }^{7} \text { Valószínű stroke: } 5\end{array}$ \\
\hline
\end{tabular}

Megjegyzések: az álpozitivitás okai (első indexben jelezve)

${ }^{1}$ csak a horizontális fejimpulzust vizsgáltuk;

${ }^{2}$ covert saccadok nem láthatóak a müszer nélkül;

${ }^{3}$ centrális típusú nystagmus stroke-ot jelzett;

${ }^{4}$ akut halláscsökkenés pozitív fejimpulzusteszttel, a szédülés centrális vagy perifériás jellege nem dönthető el vizsgálati módszereinkkel;

${ }^{5}$ Ménière-roham oldódási fázisában végeztük el a fejimpulzustesztet, amely ekkor negatív volt;

${ }^{6}$ a beteg congenitalis nystagmusa és skew deviációja évek óta fennállt, tévesen ítéltük frissnek és centrálisnak, egy másik betegnél a végállású nystagmust ítéltük tévesen tekintésirányúnak;

7a képalkotó vizsgálatok elégtelen érzékenysége az apró lacunaris eredetű infarktusok igazolására (a koponya-MR-vizsgálatok kisérbetegséget jeleztek és 1-nél több stroke-rizikófaktor állt fenn).

AVS = akut vestibularis szindróma; HINTS: (head impulse test) fejimpulzusteszt, (direction-changing nystagmus) irányváltó nystagmus, (test of skew deviation) a skew deviáció vizsgálata 


\section{Limitáció}

Meg kell jegyezni, hogy a tanulmányunkban kapott eredmények értékelését korlátozza az, hogy a vestibularis neuritisnek diagnosztizált betegeknél az SBO-on történt natív koponya-CT-vizsgálaton túlmenően egyéb képalkotó vizsgálat nem történt. Befolyásolhatja az adatok értékelését az is, hogy a hátsóscala-területi stroke neuroradiológiai verifikálását különböző képalkotó módszerekkel ( 3 T és 1,5 T térerőn MRI, CT) és különböző vizsgálati protokollokkal végeztük.

\section{Következtetések}

A kvantitatív, müszeres HINTS plusz módszer segítségével végzett vizsgálataink az AVS-sel jelentkező betegek kétharmadában perifériás vestibularis eredetet jeleztek, amelynek hátterében többségében vestibularis neuronitist állapítottunk meg. Az AVS képében jelentkező, a múszeres HINTS plusz módszerrel VB-stroke-nak véleményezett esetek 60,5\%-ában (23 eset) izolált AVS jelentkezett, amelynek előfordulási gyakorisága megfelel más, széles körü epidemiológiai felmérések eredményeinek, és felhívja a figyelmet a differenciáldiagnosztikát lehetővé tévő, újonnan bevezetett, betegágy melletti vizsgálatok alkalmazásának jelentőségére. A sürgősségi ellátás során a vizsgált AVS-es esetek 99\%-ában készült koponya-CT-vizsgálat, amely arra utal, hogy az akut ellátás során a perifériás és centrális vestibularis kórképek elkülönítése a jelenlegi ellátásban problematikus.

A múszeres HINTS plusz vizsgálattal tévesen strokenak diagnosztizált, álpozitív eset előfordulhat. Az izolált AVS képében jelentkező, AICA-területi stroke-ra utaló tüneteket mutató, de negatív képalkotó vizsgálati eredményt adó esetek egy részének hátterében virális labyrinthitis állhat. A beteg szempontjából azonban magasabb kockázatot jelent, ha a stroke diagnózisának felállítását elmulasztjuk (álnegatív eset), mintha helytelenül perifériás kórkép helyett stroke-ot véleményezünk. Stroke mellett elsősorban a vascularis rizikófaktorok többszörös jelenléte szól. Vizsgálatunkban a múszeres HINTS plusz vizsgálattal perifériás eredetűnek diagnosztizált esetekben a későbbi utánkövetés során centrális kórképre nem derült fény, amely arra utal, hogy a paradigma szenzitivitása a stroke diagnosztizálására magas.

A müszeres HINTS plusz vizsgálat a fizikális HINTS plusz vizsgálat hatékonyságát javította a stroke kizárására a perifériás neuritis inferior esetek kimutatásával és a covert saccadok miatt nem diagnosztizálható neuritis superior esetek detektálásával.

Vizsgálatunk alapján megállapítható, hogy a múszeres HINTS plusz vizsgálati módszer alkalmazása növeli a sürgősségi szédülésdiagnosztika hatékonyságát, a potenciálisan életveszélyes kórképek kiszűrésével fokozza a betegbiztonságot, a felesleges vizsgálatok mellőzésével csökkenti a betegek sugárterhelését, lerövidíti a hospitalizáció idejét és jelentősen csökkenti a költségeket.
Anyagi támogatás: A szerzők anyagi támogatásban nem részesültek.

Szerzôi munkamegosztás: T. T. L.: Irodalomkutatás, a klinikai vizsgálatok elvégzése, a kézirat megszövegezése és ellenőrzése, táblázatok, ábrák készítése. M. A.: A klinikai vizsgálatok elvégzése, a kézirat megszövegezése és ellenőrzése. K. I., N. Cs., V. Á., P. Á., Sz. F.: Radiológiai vizsgálatok elvégzése és értékelése. G. T., S. P., T. T., Sz. Á.: Irodalomkutatás, a kézirat megszövegezése és ellenőrzése. A cikk végleges változatát valamennyi szerző elolvasta és jóváhagyta.

Érdekeltségek: A szerzőknek nincsenek érdekeltségeik.

\section{Irodalom}

[1] Varga Cs, Nagy F, Drubits K, et al. Analysis of patients applying for emergency treatment with vertigo related symptoms. [A sürgősségi ellátásban szédüléssel jelentkező betegek adatainak elemzése.] Ideggyogy Szle. 2014; 67: 193-200. [Hungarian]

[2] Mike A, Tamás TL, Tompos T. Diagnostic of dizziness as emergency. [Szédüléssel járó kórképek sürgősségi diagnosztikája.] Előadás, elhangzott a Nyugat-Pannon Neurológiai Fórumon Nagykanizsán, 2016. december 1-jén. [Hungarian]

[3] Szirmai Á. Dizziness in daily routine. [Szédülés a mindennapi gyakorlatban.] Fül-orr-gégegyógyászat, 2011; 67: 201-207. [Hungarian]

[4] Tamás TL, Garai T, Tompos T, et al. Vertigo in the emergency department: new bedside tests. [Szédülés vizsgálata a sürgősségi osztályon: új, ágy melletti diagnosztikai eljárások.] Orv Hetil. 2016; 157: 403-409. [Hungarian]

[5] Büki B. Vertigo as emergency. In: Büki B. Vertigo. [Büki B. A szédülés, mint sürgősségi kórkép. In: Büki B. Szédülés.] Medicina Könyvkiadó, Budapest, 2017; pp. 21-28. [Hungarian]

[6] Nagy F. Emergency care of complaints with dizziness. [Szédüléssel járó panaszok sürgősségi ellátása.] Orvtovábbk Szle. 2017; 24: 19-23. [Hungarian]

[7] Kerber KA, Meurer WJ, West BT, et al. Dizziness presentations in U.S. emergency departments 1995-2004. Acad Emerg Med. 2008; 15: 744-750.

[8] Kattah JC, Talkad AV, Wang DZ, et al. HINTS to diagnose stroke in the acute vestibular syndrome: three-step bedside oculomotor examination more sensitive than early MRI diffusionweighted imaging. Stroke 2009; 40: 3504-3510.

[9] Newman-Toker DE, Kerber KA, Hsieh YH, et al. HINTS outperforms $\mathrm{ABCD} 2$ to screen for stroke in acute continuous vertigo and dizziness. Acad Emerg Med. 2013; 20: 986-996.

[10] Mantokoudis G, Tehrani AS, Wozniak A, et al. VOR gain by head impulse video-oculography differentiates acute vestibular neuritis from stroke. Otol Neurotol. 2015; 36: 457-465.

[11] Newman-Toker DE, Edlow JA. TiTrATE: a novel, evidencebased approach to diagnosing acute dizziness and vertigo. In: Newman-Toker DE, Kerber KA, Meurer WJ, et al. (eds.) Emergency neuro-otology: diagnosis and management of acute dizziness and vertigo. Elsevier, Philadelphia, 2015; pp. 579-599.

[12] Tarnutzer AA, Berkowitz AL, Robinson KA, et al. Does my dizzy patient have a stroke? A systematic review of bedside diagnosis in acute vestibular syndrome. CMAJ 2011; 183: E571-E592.

[13] Newman-Toker DE, Hsieh YH, Camargo CA Jr., et al. Spectrum of dizziness visits to US emergency departments: cross-sectional analysis from a nationally representative sample. Mayo Clin Proc. 2008; 83: 765-775.

[14] Nagy F. Diagnosis of dizziness. In: Gerlinger I. (ed.) Symptom oriented otorhinolaryngology. [A szédülések diagnosztikája. In: 
Gerlinger I. (szerk.) Tünetorientált fül-orr-gégészet.] Medicina Könyvkiadó, Budapest, 2013; pp. 79-100. [Hungarian]

[15] Savitz SI, Caplan LR, Edlow JA. Pitfalls in the diagnosis of cerebellar infarction. Acad Emerg Med. 2007; 14: 63-68.

[16] Newman-Toker DE, Kerber KA. Misdiagnosing dizzy patients: common pitfalls in clinical practice. In: Newman-Toker DE, Kerber KA, Meurer JW, et al. (eds.) Emergency neuro-otology: diagnosis and management of acute dizziness and vertigo. Elsevier, Philadelphia, 2015; pp. 565-575.

[17] Grad A, Baloh RW. Vertigo of vascular origin. Clinical and electronystagmographic features in 84 cases. Arch Neurol. 1989; 46: 281-284.

[18] Neuhauser H, Leopold M, von Brevern M, et al. The interrelations of migraine, vertigo, and migrainous vertigo. Neurology 2001; 56: 436-441.

[19] Newman-Toker DE. Diagnosing dizziness in the emergency department. PhD Thesis, Johns Hopkins University, 2007.

[20] Hwang DY, Silva GS, Furie KL, et al. Comparative sensitivity of computed tomography vs. magnetic resonance imaging for detecting acute posterior fossa infarct. J Emerg Med. 2012; 42: $559-565$.

[21] Lee H. Neuro-otological aspects of cerebellar stroke syndrome. J Clin Neurol. 2009; 5: 65-73.

[22] Halmagyi GM, Curthoys IS. A clinical sign of canal paresis. Arch Neurol. 1988; 45: 737-739.

[23] Brandt T, Dieterich M, Strupp M. Neuro-ophthalmological and neuro-otological examination. In: Vertigo and dizziness. Springer-Verlag, London, 2013; pp. 12-31.

[24] Brodsky MC, Donahue SP, Vaphiades M, et al. Skew deviation revisited. Surv Ophthalmol. 2006; 51: 105-128.
[25] Büki B, Hanschek M, Jünger H. Vestibular neuritis: Involvement and long-term recovery of individual semicircular canals. Auris Nasus Larynx 2017; 44: 288-293.

[26] Büki B. Symptoms of dizziness and differential diagnosis of central and peripheral vertigo-novelties in knowledge and novel examination methods (In: Schmidt P. Differential diagnosis and therapy of peripheral and central vertigo in the clinical practice - actualities in general practice.) [A szédülés tünettana, a szédüléssel járó perifériás kórképek és centrális vestibularis kórképek differenciáldiagnosztikája - Új ismeretek és vizsgálómódszerek.] (In: Schmidt P. Szédüléssel járó betegségek differenciáldiagnosztikája és terápiája a mindennapi gyakorlatban - Aktualitások a háziorvoslásban.) Alapellátási Szabadegyetem - MTA Nemzetközi Tudományos Szimpózium, Győr, Városháza, 2011. február 05. Abstract book pp. 5-8.)

[27] Sylaja PN, Coutts SB, Krol A, et al. When to expect negative diffusion-weighted images in stroke and transient ischemic attack. Stroke 2008; 39: 1898-1900.

[28] Morita S, Suzuki M, Iizuka K, et al. False-negative diffusionweighted MRI in acute cerebellar stroke. Auris Nasus Larynx 2011; 38: 577-582.

[29] Marra F, Ruckenstein J, Richardson K. A meta-analysis of stroke risk following herpes zoster infection. BMC Infect Dis. 2017; 17: 198.

(Tamás T. László dr., Györ, Vak Bottyán u. 14/A, 9028 e-mail: ltamas@gyor.net)

\section{"Violenta nemo imperia continuit diu: moderata durant." (Seneca) (Az erőszakos uralmat senki sem tarthatja fenn sokáig: a mérsékelt uralom tartós.)}

